\title{
Effect of Muntingia calabura L. Leaf Extract on Blood Glucose Levels and Body Weight of Alloxan-Induced Diabetic Mice
}

\author{
Tridiganita Intan Solikhah ${ }^{1, *}$, Gahastanira Permata Solikhah ${ }^{2}$
}

Tridiganita Intan Solikhah ${ }^{1, *}$ Gahastanira Permata Solikhah²

'Division of Veterinary Clinic, Faculty of Veterinary Medicine, Universitas Airlangga, Surabaya, INDONESIA

${ }^{2}$ Cahaya Petclinic, Mojokerto, INDONESIA

\section{Correspondence}

\section{Tridiganita Intan Solikhah}

Division of Veterinary Clinic, Faculty of Veterinary Medicine, Universitas Airlangga, Surabaya, INDONESIA.

E-mail: tridiganita-intan-s@fkh.unair.ac.id History

- Submission Date: 19-07-2021;

- Review completed: 11-08-2021;

- Accepted Date: 16-08-2021.

DOI : 10.5530/pj.2021.13.184

Article Available online

http://www.phcogj.com/v13/i6

\section{Copyright}

(C) 2021 Phcogi.Com. This is an openaccess article distributed under the terms of the Creative Commons Attribution 4.0 International license.

\begin{abstract}
Objective: To evaluate the effect of Muntingia calabura L. leaf extract on the blood glucose level and weight of alloxan-induced diabetic mice. Methods: The mice were injected using $150 \mathrm{mg} / \mathrm{kg}$ of alloxan intraperitoneally to induce diabetes. Blood glucose level was tested before alloxan injection and 5 days after injection to confirm diabetes development. M. calabura leaf extract with 100 and $300 \mathrm{mg} / \mathrm{kg}$ and 600 $\mu \mathrm{g} / \mathrm{kg}$ of glibenclamide was given orally for 14 days. Results: The statistical results showed a significant decrease in blood glucose level, especially on day-7 and day-14 in the $M$. calabura leaf extract treatment group and glibenclamide treatment group compared to the model control group. There was an increase of weight on day-7 and day-14 in the $M$. calabura leaf extract group and a significant decrease in weight on day-7 in the glibenclamide group compared to the model control group. Conclusion: $M$. calabura leaf extract had a significant antidiabetic effect that can normalize the weight of alloxan-induced diabetic mice Key words: Alloxan, Diabetes, Muntingia calabura leaf, Mice.
\end{abstract}

\section{INTRODUCTION}

Diabetes Mellitus (DM) is a metabolic disease characterized by hyperglycemia caused by insufficiency in the number and function of insulin which led to an abnormality in the metabolism of carbohydmicees, lipid, and protein ${ }^{1,2}$. DM is a noncontagious disease in Indonesia with increasing prevalence and may lead to fatal complications ${ }^{3}$. Factors related to the increased prevalence of DM in Indonesia include changes in dietary patterns, obesity, urbanization, and lack of exercise ${ }^{4}$. Several acute and chronic complications can affect DM patients due to oxidative stress caused by hyperglycemia ${ }^{5}$.

The insulin hormone has the main function of regulating blood glucose levels. Lack of insulin or inadequate activity of the hormone due to reduced sensitivity of the insulin receptor can cause an abnormality in blood glucose homeostasis ${ }^{6}$. Exposure to the diabetogenic substance of alloxan reduces the level of insulin and disrupts blood glucose homeostasis. Alloxan is a diabetogenic substance that is cytotoxic to the pancreatic islets ${ }^{7}$.

The current oral medicines for diabetes mellitus are in the sulfonylurea, biguanide, and acarbose groups ${ }^{8}$. One of the medicines widely used in Indonesia is glibenclamide. Synthetic drugs, aside from expensive, often cause side effects9. On the other hand, natural drugs from selected herbal medicines cost cheaper and have a relatively easy method of application ${ }^{10-12}$.

One of the herbal medicines in Indonesia that can be used for diabetes mellitus is M. calabura, especially its leaves. M. calabura is a fast-growing wild plant that is easy to obtain. The leaves of $M$. calabura can be utilized as an antidiabetic drug. $M$. calabura leaf contains high antioxidants. Substance screening from $M$. calabura leaves showed alkaloid, flavonoid, tannin, saponin, triterpenoid, and steroid ${ }^{13,14}$

Several previous studies stated that $M$. calabura leaf has potential as an antidiabetic drug, including a study by Zulham, Hendrarti, and Wahyuni (2019) ${ }^{15}$ who showed that ethanol extract from M. calabura leaves with 50,100 , and $150 \mathrm{mg} / \mathrm{kg}$ obtained from macemiceion could reduce blood glucose level in alloxan-induced diabetic mice. The results from Herlina, Amriani, Solihah, and Sintya $(2018)^{16}$ also showed that ethanol extract from M. calabura leaves with 65,130 , and $260 \mathrm{mg} / \mathrm{kg}$ could reduce blood glucose levels to $28.90 \%, 32.16 \%$, and $35.66 \%$ in male albino mice induced by alloxan.

Based on the statements above, the author is interested in conducting a further study to determine the effect of graded dose of $M$. calabura leaf extract on blood glucose level and body weight of alloxaninduced diabetic mice. This study is expected to be a new source of information for the public regarding the benefit of $M$. calabura leaves as an optimal antidiabetic herbal medicine.

\section{MATERIALS AND METHODS}

\section{Prepamiceion of animals}

Male mice (Mus musculus L.), aged \pm 3 months, weighing between 25-35 grams were used in this study. The cage used was a plastic caged covered with wire mesh. Every other day, the cage's bottom was coated in $1 \mathrm{~cm}$ high husks. The scientific range for light, moisture, and room temperature were adjusted. Ethical code, institutional, and national regulation on live animals were strictly observed. The Health Research Ethical Clearance Commission, Faculty of Dental Medicine, Airlangga University granted ethical permission for the animals used in this investigation, with the number 507/HRECC. FODM/XI/2020. 


\section{Prepamiceion of extract}

M. calabura leaves were rinsed from dust and heated in an oven at $60^{\circ} \mathrm{C}$. The leaves were then ground with a leaf grinder with a miceio of 1:7 of M. calabura leaf powder immersed in $96 \%$ ethanol. They were mixed and let sit still at room tempemiceure for 2 hours. Afterward, the leaves were filtered, and macemicees were sepamiceed and remacemiceed with a miceio of 1:4 with an addition of $96 \%$ of ethanol. All macemicees were evapomiceed at $60^{\circ} \mathrm{C}$ after filtered to obtain the thick extract. The solvent used was Carboxyl Methyl Cellulose (CMC) with $0.5 \%$ concentmiceion to obtain the desired extract.

\section{Flavonoids Test}

A solution of hydrochloric alcohol from $2 \mathrm{~mL}$ of amyl alcohol was added with $\mathrm{Mg}$ powder and $5 \mathrm{~mL}$ of $M$. calabura leaf extract, then vigorously shaken and let to sepamicee. The formation of the yellow amyl alcohol layer showed a positive result.

\section{Tannins Test}

Steasny reagent was added to the solution of M. calabura leaf extract, then heated in a water bath to obtain a pink deposit. The result was filtered and the filtmicee from the solution was satumiceed with $\mathrm{NaCl}$ and added with gelatin. The formation of white deposits showed a positive result.

\section{Alkaloids Test}

2 grams of $M$. calabura leaf extract were added to $50 \mathrm{~mL}$ of water, heated for 5 minutes, and filtered. Mayer and Dragendorff test was performed by inserting $5 \mathrm{~mL}$ of $M$. calabura leaf extract into a reaction tube. The formation of white deposit showed a positive result in the Mayer test and the formation of orange deposit showed a positive result in the Dragendorff test

\section{Saponins test}

A reaction tube containing $10 \mathrm{~mL}$ of $M$. calabura leaf extract shaken for 10 seconds and let still for 10 minutes. The formation of bubbles or foam showed a positive result.

\section{Polyphenol test}

3 drops of $\mathrm{FeCl}$ reagent were added to $5 \mathrm{~mL}$ of $M$. calabura leaf extract. The formation of a blue-green color showed a positive result of polyphenol.

\section{Quinone test}

$\mathrm{NaOH}$ of $1 \mathrm{~N}$ was added to $5 \mathrm{~mL}$ of $M$. calabura leaf extract. The formation of a red color showed a positive result of quinone.

\section{Steroids and Terpenoids test}

$5 \mathrm{~mL}$ of ether solution of $M$. calabura leaf extract was evapomiceed in the evapomiceor cup, and 1 drop of thick $\mathrm{H}_{2} \mathrm{SO}_{4}$ and 2 drops of anhydrous acetic acid were added to the resulted residue from the extract solution. The formation of a green color showed a positive result of steroids, and the formation of a brown color showed a positive result of terpenoid.

\section{Acute toxicity test}

M. calabura leaf extract with $5 \mathrm{mg} / \mathrm{kg}$ was given to 6 male mice orally using a probe and was observed every 6 hours for 48 hours. The toxic dose was confirmed if there are 3 or more mice died. However, if only one mice died, then the same dose was given to confirm non-toxicity. Repetition of the procedure with a higher dose of 50,100, and $2000 \mathrm{mg} /$ $\mathrm{kg}$ was performed if there was no death.

\section{Antidiabetic test}

The mice were divided into 5 groups, each consisted of 6 mice. Alloxan with $150 \mathrm{mg} / \mathrm{kg}$ was dissolved in a $\mathrm{NaCl} 0.9 \%$, induced peritoneally, and given to all groups of mice except the normal control group. After 5 days of alloxan injection, mice with blood glucose levels higher than $200 \mathrm{mg} / \mathrm{dL}$ were included for further treatment. The groups were divided into normal control group which was without alloxan, model control group group with only alloxan, extract treatment group with $100 \mathrm{mg} / \mathrm{kg}$ and $300 \mathrm{mg} / \mathrm{kg}$ of $M$. calabura leaf extract, and positive control group $600 \mu \mathrm{g} / \mathrm{kg}$ of glibenclamide. All treatments were applied orally using a probe. On days 1,7 , and 14, blood glucose level was checked on all groups using instant Accu check instan glucometer ${ }^{17}$.

\section{Data analysis}

SPSS ver. 22 software was used to analyze all data in this study. Oneway ANOVA was used to determine the significance. Tukey was used to test the difference between groups. Differences were considered significant if $\mathrm{P}<0.05$.

\section{RESULTS AND DISCUSSION}

\section{Phytochemical screening of $M$. calabura leaf extracts}

Table 1 shows the results of the phytochemical analysis of M. calabura leaf extract in this study.

\section{Toxicity test}

M. calabura leaf extract does not cause death in mice and the dose is safe to $2000 \mathrm{mg} / \mathrm{kg} \mathrm{BW}$ within 6 hours interval of observation for 48 hours.

\section{Antidiabetic effect of M. calabura leaf extracts on blood glucose levels}

On days 1,7 , and 14 , the results of this study revealed significant increase blood glucose levels in the model control group compared to the normal control group $(\mathrm{P}<0.05)$. Meanwhile, the $M$. calabura group and glibenclamide group showed a significant reduction in blood glucose level compared to the model control group $(\mathrm{P}<0.05)$. Effects of M. calabura leaf extracts on blood glucose levels in mice after 14 days treatment can be seen in Table 2.

\section{Antidiabetic effect of $M$. calabura leaf extracts on body weight}

The statistical test results showed weight gain on day 7 and day 14 in the control group and the M. calabura leaf extract group. The glibenclamide group showed significant weight loss on day 7 compared to the model control group. Effect of $M$. calabura leaf extract on body weight in diabetic mice during 14 days can be seen in Table 3 .

\section{DISCUSSION}

The active substances in M. calabura include alkaloid, flavonoid, saponin, tannin, polyphenol, quinone, and steroids. The flavonoid content in M. calabura leaf can reduce blood glucose levels. Flavonoid is one of the most found secondary metabolic substances in plant tissues ${ }^{18}$. Flavonoid is known to capture free radicals or function as a natural antioxidant ${ }^{19,20}$. This activity enables flavonoids to capture or neutralized free radicals (such as ROS or RNS) related to the phenolic $\mathrm{OH}$ group to repair damaged tissues after induced by alloxan ${ }^{21}$. Flavonoids can also protect the lipid membrane from oxidative damage. Therefore, lipid peroxidation can be inhibited and an increased level of malondialdehyde (MDA) can be prevented ${ }^{22,23}$. 
Table 1: Phytochemistry of the ethanolic leaf extracts of Muntingia calabura L.

\begin{tabular}{cc}
\hline Phytochemical test & Ethanol extract \\
\hline Alkaloids & + \\
Flavonoids & + \\
Saponins & + \\
Tannins & + \\
Polyphenol & + \\
Quinone & + \\
Steroids & + \\
Terpenoids & -
\end{tabular}

Note: (+) showed a positive result from M. calabura leaf extracts

Table 2: Effects of $M$. calabura leaf extracts on blood glucose levels in mice after 14 days treatment.

\begin{tabular}{lccc}
\hline Groups & \multicolumn{3}{c}{} \\
\hline & Day 1 & Blood glucose $(\mathrm{mg} / \mathrm{dL})$ & Day 14 \\
\hline Control & $100.6 \pm 2.7$ & $91.2 \pm 4.32$ & $102.2 \pm 1.3$ \\
Model & $381.6 \pm 2.07^{*}$ & $395.2 \pm 1.64^{* * *}$ & $391.6 \pm 2.07^{*}$ \\
Glibenclamide & $401 \pm 4.12^{* \#}$ & $226.8 \pm 4.09^{* * * \# \#}$ & $200.8 \pm 4.44^{* \#}$ \\
M. calabura leaf extract 100 & $387 \pm 3.67^{* \#}$ & $308 \pm 3.67^{* * \# \# \#}$ & $213 \pm 3.67^{* \#}$ \\
M. calabura leaf extract 300 & $400.2 \pm 3.27^{* \#}$ & $178 \pm 1.22^{* * * \# \#}$ & $166.2 \pm 4.44^{* \#}$
\end{tabular}

The data were express in mean \pm SD ( $n=6$ of each group).

${ }^{*} P<0.05$ (compared with normal control group); ${ }^{* * *} P<0.001$ (compared with normal control group); $P<0.05$ (compared with model control group); ${ }^{\# \#} P<0.001$ (compared with model control group).

Table 3: Effect of M. calabura leaf extract on body weight in diabetic mice during 14 days.

\begin{tabular}{lccc}
\hline Groups & \multicolumn{3}{c}{ Body weight (g) } \\
\hline Control & Day 1 & Day 7 & Day 14 \\
Model & $25.4 \pm 1.52$ & $27 \pm 3.67$ & $28 \pm 3.39$ \\
Glibenclamide & $23.6 \pm 2.88$ & $23.2 \pm 3.21^{*}$ & $24.8 \pm 4.32^{*}$ \\
M. calabura leaf extract 100 & $21.8 \pm 1.2$ & $20.6 \pm 1.82^{* *}$ & $23.6 \pm 1.67$ \\
M. calabura leaf extract 300 & $22.6 \pm 3.65$ & $23.6 \pm 2.51$ & $24 \pm 3.16$ \\
\hline
\end{tabular}

The data were express in mean $\pm S D$ ( $n=6$ of each group).

${ }^{*} P<0.05$ (compared with normal control group); ${ }^{\#} P<0.05$ (compared with model control group).

Alkaloids can regenemicee damaged pancreatic $\beta$ cells. The antioxidant activity from $M$. calabura leaf is also high and could repair damaged pancreatic $\beta$ cells. Antioxidant activity can capture free radicals that result in the repair of damaged pancreatic $\beta$ cells causing DM 1 . This leads to increased insulin in the body thus reduced blood glucose in the body $y^{24,25}$.

Saponin is a substance containing the isoprene structure of $\mathrm{CH}_{2}=\mathrm{C}\left(\mathrm{CH}_{3}\right)-\mathrm{CH}=\mathrm{CH}_{2}^{26}$. This saponin can be detected based on the ability to form foam because saponin acts like a soap. Saponin is an active surface substance grouped as triterpene glycosides. Saponin contained in $M$. calabura leaf supports the potential of the plant as a diabetic drug. Physiologically, saponin is an active substance that inhibits the absorption of glucose and prevents increased glucose in the blood, thus can be used to treat diabetes ${ }^{27}$. Tannin can stimulate glucose and fat metabolism, preventing these two energy sources from accumulating in the bloodstream. This substance also has hypoglycemic activity by increasing glycogenesis ${ }^{28}$.

Polyphenol can alleviate oxidative stress by contributing hydrogen atoms from the hydroxyl aromatic group of polyphenol to bind free radicals and release them through the excretion system, preventing a chain reaction from superoxide to hydrogen superoxide. Polyphenol has been shown to protect pancreatic cells against the harmful effects of free radicals generated under chronic hyperglycemia conditions. Antioxidant administration can enhance pancreatic $\beta$ cell mass and keep insulin levels stable ${ }^{29,30}$. Steroids lowered blood glucose levels through altering insulin activity at the cellular level, distal insulin receptors, and reduced glucose production in the liver ${ }^{31}$.
In this study, the mice used were male mice because they have a more stable biological condition compared to female mice, which are not affected by the estrous cycle. Other than that, male mice also have faster drug metabolism. Mice were adapted for 2 weeks to the lifestyle in their new environment and to avoid stress during treatment.

Diabetes mellitus can be caused by several factors. These factors include genetic, nutrition, diabetogenic substance, and free radicals (oxidative

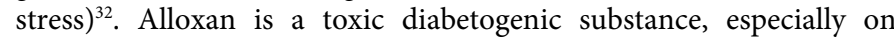
pancreatic $\beta$ cells. Alloxan given to animal models such as mice can cause diabetes. The entrance of alloxan into pancreatic cells initiates the cytotoxic mechanism of alloxan. The diabetogenic property of alloxan is determined by the speed with which it is collected. Damage to cells is caused by a combination of mechanisms, including the oxidation of the sulfhydryl group and the production of free radicals. Alloxan damages pancreatic $\beta$ cells by destroying biological components that contain the sulfhydryl group, cysteine amino acids, and proteins that attach to the $\mathrm{SH}$ group (including enzymes containing the $\mathrm{SH}$ group) ${ }^{33}$. Alloxan reacts with two $\mathrm{SH}$ groups that bind the sides of protein or amino acid and create a disulfide bond, which inactivates the protein and leads to the damaged function of the protein ${ }^{34,35}$. Alloxan with 150 $\mathrm{mg} / \mathrm{kg}$ induced intraperitoneally can increase the level of blood glucose and damage in the pancreatic $\beta$ cells of mice. The mice were considered hyperglycemic if the blood glucose level reached $>200 \mathrm{mg} / \mathrm{dl}$.

Based on the result of One-Way ANOVA on day 14, M. calabura leaf extract with 100 and $300 \mathrm{mg} / \mathrm{kg}$ provided a significant effect in reducing blood glucose level compared to the model control group. M. calabura leaf was insignificantly different from the positive control. This showed 
that $M$. calabura leaf with 100 and $300 \mathrm{mg} / \mathrm{kg}$ provided a significant effect in reducing blood glucose levels because they provide similar effects to glibenclamide as a positive control.

The positive control group that was given glibenclamide showed a significant decrease in blood glucose compared to the model control group. Glibenclamide is an oral hypoglycemic drug in the group of sulfonylurea that has a therapeutic effect in reducing blood glucose levels. Therefore, it is chosen as a comparison in this study. This is because glibenclamide works by increasing insulin secretion. Glibenclamide works by inducing the secretion of insulin hormone from the granules of the $\beta$ cells in pancreatic Langerhans islets. Its interaction with ATP - sensitive $\mathrm{K}$ channel in $\beta$ cells membrane cause membrane depolarization, which will open the Ca channel. After the $\mathrm{Ca}$ channel opens, $\mathrm{Ca}^{2+}$ ions will go inside $\beta$ cells and induce granules with insulin that results in insulin secretion ${ }^{36,37}$.

The results of this study showed that weight loss occurred on day 7 in the model control group because diabetes mellitus patients often had sudden significant weight loss due to insufficient insulin. Therefore, glucose provides a very low energy source in the body and the body took energy from fat and muscles which causes to weight loss. The administmiceion of $M$. calabura leaf extract in this study helped normalized the weight of mice because the ethanol extract of $M$. calabura leaf contains antioxidant substances such as flavonoid and saponin that can normalize weight.

\section{CONCLUSION}

The administmiceion of $M$. calabura leaf extract in this study effective in decrease blood glucose level and can normalized the weight of diabetic mice. However, further studies are needed to determine the microscopic effect on pancreatic and liver cells of diabetic mice after administmiceion of $M$. calabura leaf extract.

\section{COMPETING INTERESTS}

The authors declare that they have no competing interests.

\section{REFERENCES}

1. Onwuli DO, Brown H, Ozoani HA. Antihyperglycaemic effect of Tetracarpidium Conophorum Nuts in alloxan induced diabetic female albino rats. ISRN Endocrinol. 2014;2014:1-4. doi:10.1155/2014/124974

2. Vlad I, Popa AR. Epidemiology of diabetes mellitus: A current review. Rom J Diabetes Nutr Metab Dis. 2012;19(4):433-440. doi:10.2478/v10255-012-0050-0

3. Olokoba $A B$, Obateru OA, Olokoba LB. Type 2 diabetes mellitus: A review of current trends. Oman Med J. 2012;27(4):269-273. doi:10.5001/omj.2012.68

4. Al-Goblan AS, Al-Alfi MA, Khan MZ. Mechanism linking diabetes mellitus and obesity. Diabetes, Metab Syndr Obes Targets Ther. 2014;7:587-591. doi:10.2147/DMSO.S67400

5. Zhang Y, Wu L, Ma Z, Cheng J, Liu J. Anti-hyperlipidemic activities of flavonoids from corn silk on STZ-Induced diabetic mice. Molecules. 2016;21(1):7. doi:10.3390/molecules21010007

6. Al-Qudah MMA, Haddad MA, El-Qudah JMF. The effects of aqueous ginger extract on pancreas histology and on blood glucose in normal and alloxan monohydrate-induced diabetic rats. Biomed Res. 2016;27(2):350-356.

7. Diab RAH, Fares $M$, Abedi-Valugerdi $M$, Kumagai-Braesch M, Holgersson J, Hassan M. Immunotoxicological effects of streptozotocin and alloxan: in vitro and in vivo studies. Immunol Lett. 2015;163(2):193-198. doi:10.1016/j.imlet.2014.12.006

8. Lopamudra Dhar Choudhury R. A comparative study of miglitol and acarbose add on therapy intended for better glycaemic control in type 2 diabetes mellitus. Int J Curr Res Rev. 2016;8(24):33-40.
9. Srivali N, Thongprayoon C, Cheungpasitporn W, Ungprasert P. Acute pancreatitis in the use of canagliflozin: a rare side-effect of the novel therapy for type 2 diabetes mellitus. J Basic Clin Pharm. 2015;6(3):101-102. doi:10.4103/0976-0105.160753

10. Khairullah AR, Solikhah TI, Ansori ANM, et al. A review of an important medicinal plant: Alpinia galanga (L.) willd. Syst Rev Pharm. 2020;11(10):387-395.

11. Khairullah AR, Solikhah TI, Ansori ANM, et al. Medicinal importance of Kaempferia galanga L. (Zingiberaceae): A comprehensive review. J Herbmed Pharmacol. 2021;10(3):281-288.

12. Khairullah AR, Solikhah TI, Ansori ANM, et al. Review on the Pharmacological and Health Aspects of Apium Graveolens or Celery : An Update. Syst Rev Pharm. 2021;12(1):606-612.

13. Gurning $\mathrm{K}$, Sinaga $\mathrm{H}$. In vitro anti-diabetic potential extract test of Seri (Muntingia Calabura L.) leaves. Asian J Pharm Res Dev. 2020;8(6):39-41. doi:10.22270/ajprd.v8i6.874

14. Ansori ANM, Kharisma VD, Solikhah TI. Medicinal properties of Muntingia calabura L.: A Review. Res J Pharm Technol. 2021;14(8):4505-4508

15. Zulham Z, Hendrarti W, Wahyuni N. Antihyperglycemic activity of Muntingia calabura L. on alloxan-induced diabetic rats. J Pharm Med Sci. 2019;3(2).

16. Herlina H, Amriani A, Solihah I, Sintya R. Antidiabetic activity test of ethanolic seri leave's (Muntingia calabura L.) extract in male rats induced by alloxan. Sci Technol Indones. 2018;3(1):7-13.

17. Saleh FA, El-Darra N, Raafat K. Hypoglycemic effects of Prunus cerasus L. pulp and seed extracts on alloxan-induced diabetic mice with histopathological evaluation. Biomed Pharmacother. 2017;88:870-877. doi:10.1016/..biopha.2017.01.155

18. Deng N, Chang E, Li M, et al. Transcriptome characterization of Gnetum parvifolium reveals candidate genes involved in important secondary metabolic pathways of flavonoids and stilbenoids. Front Plant Sci. 2016;8:1-13

19. Lu Y, Chen $\mathrm{Q}, \mathrm{Bu}$ Y, et al. Flavonoid accumulation plays an important role in the rust resistance of Malus plant leaves. Front Plant Sci. 2017;8:1-13. doi:10.3389/fpls.2017.01286

20. Kaurinovic B, Vastag D. Flavonoids and Phenolic Acids as Potential Natural Antioxidants. (Shalaby E, ed.). IntechOpen; 2019. doi:10.5772/intechopen.77838

21. Hidayat R, Hayati L, Parisa N. Indonesian plants with potential as an anti-diabetes mellitus agent. Eureka Herba Indones. 2020;1(2):2831. doi:10.37275/EHI.v1i2.7

22. Zeng $Y$, Song J, Zhang $M$, Wang $H$, Zhang $Y$, Suo $H$. Comparison of in vitro and in vivo antioxidant activities of six flavonoids with similar structures. Antioxidants. 2020;9(8):1-14. doi:10.3390/ antiox9080732

23. Lv D, Cheng $X$, Tang L, Jiang M. The cardioprotective effect of total flavonoids on myocardial ischemia/reperfusion in rats. Biomed Pharmacother. 2017;88:277-284. doi:10.1016/j.biopha.2017.01.060

24. Semwal DK, Kumar A, Aswal S, Chauhan A, Semwal RB. Protective and therapeutic effects of natural products against diabetes mellitus via regenerating pancreatic $\beta$-cells and restoring their dysfunction. Phyther Res. Published online 2020:1-12. doi:10.1002/ptr.6885

25. Kwon SJ, Hwang SJ, Jung $Y$, et al. A synthetic Nitraria alkaloid isonitramine protects pancreatic $\beta$-cell and attenuates postprandial hyperglycemia. Metabolism. 2017;70:107-115. doi:10.1016/j. metabol.2017.02.002

26. Chabib L, Muhtadi WK, Rizki MI, Rahman RA, Suhendri MR, Hidayat A. Potential medicinal plants for improve the immune system from Borneo Island and the prospect to be developed as nanomedicine. MATEC Web Conf. 2018;154:1-6. doi:10.1051/ matecconf/201815404006 
27. Park S-J, Lee D, Kim D, et al. The non-saponin fraction of Korean Red Ginseng (KGC05P0) decreases glucose uptake and transport in vitro and modulates glucose production via down-regulation of the PI3K/AKT pathway in vivo. J Ginseng Res. 2020;44(2):362-372. doi:10.1016/j.jgr.2019.12.004

28. Martinez ODM, Theodoro JM V., Grancieri M, et al. Dry heated whole sorghum flour (BRS 305) with high tannin and resistant starch improves glucose metabolism, modulates adiposity, and reduces liver steatosis and lipogenesis in Wistar rats fed with a high-fat high-fructose diet. J Cereal Sci. 2021;99:1-9. doi:10.1016/j. jcs.2021.103201

29. Grzesik M, Bartosz G, Stefaniuk I, Pichla M, Namieśnik J, Sadowska-Bartosz I. Dietary antioxidants as a source of hydrogen peroxide. Food Chem. 2019;278:692-699. doi:10.1016/j. foodchem.2018.11.109

30. Dall'Asta M, Bayle M, Neasta J, et al. Protection of pancreatic $\beta$-cell function by dietary polyphenols. Phytochem Rev. 2015;14:933959. doi:10.1007/s11101-015-9429-x

31. Solikhah TI, Setiawan B, Ismukada DR. Antidiabetic activity of papaya leaf extract ( Carica Papaya L.) isolated with maceration method in alloxan-induces diabetic mice. Syst Rev Pharm. 2020;11(9):774-778.

32. Panambunan M, Pangkahila W, Budhiarta AAG. Combination treatment of vildagliptin and bay leaf (Syzygium polyanthum) extract increased pancreatic beta cells number but have no effect toward glycated albumin levels in diabetic male Wistar rats (Rattus norvegicus). Indones J Anti-Aging Med. 2019;3(2):33-37. doi:10.36675/ijaam.v3i2.43

33. Ighodaro OM, Adeosun AM, Akinloye OA. Alloxan-induced diabetes, a common model for evaluating the glycemic-control potentia of therapeutic compounds and plants extracts in experimenta studies. Medicina (B Aires). 2017;53:365-374. doi:10.1016/j. medici.2018.02.001

34. Sari MI, Ilyas S, Widyawati T, Antika MA. Effect of lawsonia innermis (linn) leaves ethanolic extract on blood glucose and malondialdehyde level in alloxan-induced diabetic rats. IOP Conf Ser Earth Environ Sci. 2018;130:1-7. doi:10.1088/1755-1315/130/1/012034

35. Andriani RD, Rahayu RP, Chairunnisa F, Wulan SN, Maligan JM Fortification of skim milk with whey protein xanthone and its effect on antihyperglycemic activities in animal model. IOP Conf Ser Earth Environ Sci. 2020;443:1-7. doi:10.1088/1755-1315/443/1/012012

36. Esmaeili $\mathrm{MH}$, Bahari $\mathrm{B}$, Salari AA. ATP-sensitive potassiumchannel inhibitor glibenclamide attenuates HPA axis hyperactivity, depression-and anxiety-related symptoms in a rat model of Alzheimer's disease. Brain Res Bull. 2018;137:265-276. doi:10.1016/j.brainresbull.2018.01.001

37. Zhou J, Kang $X$, Luo $Y$, et al. Glibenclamide-induced autophagy inhibits its insulin secretion-improving function in $\beta$ cells. Int Endocrinol. 2019;2019:1-8. doi:10.1155/2019/1265175

\section{GRAPHICAL ABSTRACT}

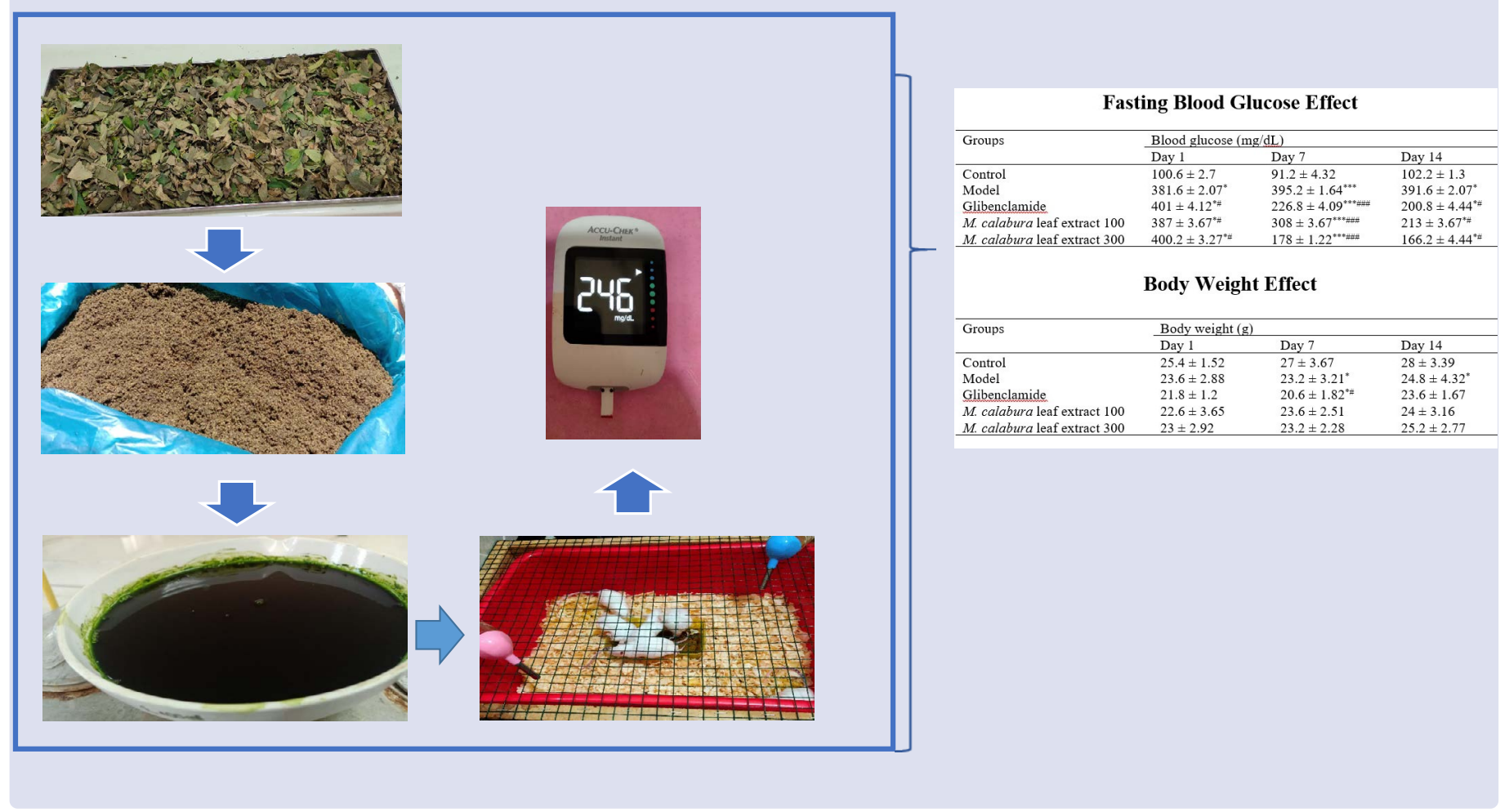




\section{ABOUT AUTHORS}

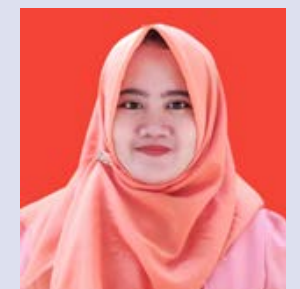

Tridiganita Intan Solikhah is a lecturer at the Faculty of Veterinary Medicine at Universitas Airlangga. She completed her undergraduate and postgraduate studies at the Faculty of Veterinary Medicine, Universitas Airlangga, Surabaya, Indonesia. The author has been a jury for a national essay competition for students throughout Indonesia. She research projects related to veterinary clinical sciences, medicinal plants and antidiabetic. The author also has several international journal publications.

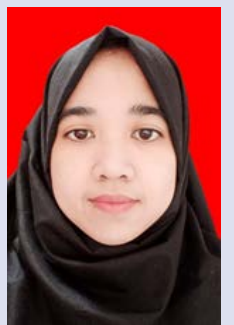

Gahastanira Permata Solikhah has a veterinary clinic that she has started since 2016 named Cahaya Petshop Petclinic which is located in Mojokerto. Her research area focused on the natural products for medicinal plants, antidiabetic, and pharmacology.

Cite this article: Solikhah TI, Solikhah GP. Effect of Muntingia calabura L. Leaf Extract on Blood Glucose Levels and Body Weight of Alloxan-Induced Diabetic Mice. Pharmacogn J. 2021;13(6): 1450-1455. 